\title{
Shear mouth associada à trauma facial - relato de caso
}

\author{
[a] Universidade Federal de Santa Maria (UFSM), Santa Maria, RS, Brasil \\ b] Equident - Odontologia Equina Avançada, Porto Alegre, RS, Brasil \\ [c] Clínica Hípica, Porto Alegre, RS, Brasil
}

*Autor correspondente

e-mail: lizzie.dietrich@gmail.com

\section{Resumo}

Biomecanicamente, uma boca em cisalha (shear mouth) é resultado de uma redução ou de uma completa ausência de mastigação de um lado, o que permite que as margens bucais dos dentes molares do maxilar e a margem lingual dos dentes molares mandibulares não sofram atrito normal. Muitas etiologias são propostas para esta doença rara. Uma hipótese é que uma infecção apical de molares possa levar a uma restrição no movimento mandibular normal por dor (Dixon et al., 2000; Dixon, 2003; Dixon \& Dacre, 2005; Easley et al., 2011). 0 objetivo deste trabalho é relatar o caso de um equino com fístula na região mandibular ventral do masseter esquerdo após trauma de face, associada a uma má oclusão do tipo mordida em cisalha (shear mouth). Um equino, macho, castrado, SRD, 15 anos, foi levado à clínica Equident para tratar uma fístula mandibular localizada na porção ventral do masseter esquerdo, com descarga fétida e purulenta há 3 anos. No exame da cavidade oral, sob sedação $0,2 \mathrm{mg} / \mathrm{kg}$ de detomidina IV, foi observada uma anormalidade dental severa: mordida em cisalha (shear mouth) e severa DGL 4 nos incisivos. Os quadrantes 200 e 300 apresentavam angulação excessiva (aproximadamente 60) e bloqueio da excursão lateral, enquanto os quadrantes 100 e 400 mantiveram a angulação normal (aproximadamente 20). Na inspeção intraoral, os dentes Triadan 310 e 311 estavam fraturados e um fragmento dentário do 310 apresentavase longitudinalmente no bordo gengival do quadrante 300. No exame radiográfico, havia radioluscência apical nos dentes Triadan 310 e 311, sugerindo fratura dos mesmos e reabsorção apical, além de presença de um sequestro no bordo ventral da mandíbula próximo à fístula. No exame bacteriológico, obteve-se Streptococcus spp., sensível à doxiciclina. No primeiro estágio de tratamento, foram feitos ajuste oclusal e exodontia dos dentes Triadan 310, 311 e seus fragmentos, com o equino em estação e sedado $(0,2 \mathrm{mg} / \mathrm{kg}$ 
detomidina IV, 0,1 mg/kg butorfanol IV, e suplementação com metade da dosagem) e com bloqueio regional do nervo mandibular com $10 \mathrm{ml}$ de lidocaína $2 \%$. No pós-operatório, foi aplicada silicone de moldagem para fechamento do alvéolo, doxiciclina oral $10 \mathrm{mg} / \mathrm{kg}$ a cada 12 horas, por 21 dias, e flunixin meglumine 1,1mg/ kg IV a cada 24 horas, por 3 dias. A limpeza do alvéolo era feita diariamente com solução iodada 2\%. Após sete dias, foi realizada a segunda etapa do tratamento, que consistiu na curetagem da fístula mandibular, remoção do sequestro e debridamento da ferida, com o equino sedado e em estação, conforme protocolo anterior. Flunixin meglumine $1,1 \mathrm{mg} / \mathrm{kg}$ IV a cada 24 horas foi aplicado por cinco dias, além da continuação da antibioticoterapia. A ferida externa foi limpa diariamente e aplicada gaze com açúcar e iodo $5 \%$. A ozonioterapia foi empregada com suporte na forma de gás para estimular cicatrização e reduzir crescimento bacteriano. No $28^{\circ}$ dia de internação foi feita a terceira etapa do tratamento, que compreendeu a exodontia do Triadan 309, em função da permanência da fístula, seguindo protocolo com animal em estação. 0 cuidado pós-operatório foi o mesmo da etapa inicial. 0 paciente recebeu alta 50 dias após internação, uma vez que se observou cicatrização intraoral e extraoral completas. Recomendou-se a realização de odontoplastia a cada quatro meses. Traumas de face podem gerar danos ósseas, dentais e/ou neurológicos que, quando não tratados, produzem transtornos mastigatórios que progressivamente geram desalinhamentos oclusais em consequência da dor localizada ou mesmo por perda da propriocepção regional. 0 tratamento proposto em etapas demonstrou-se adequado para o caso, visto que existia uma cronicidade na afecção e formação de sequestro. 0 tratamento em estação sob sedação, associado ao bloqueio regional, foi efetivo, seguro e com baixo custo, podendo ser considerado a primeira opção para quadros similares. A odontoplastia reparatória esporádica se faz essencial para o futuro deste quadro.

Palavras-chave: Fístula mandibular. Shear mouth. Boca em cisalha. 